\begin{tabular}{|c|c|c|c|c|}
\hline & $\begin{array}{l}\text { FATIIH } \\
\text { SULTAN } \\
\text { MEHMET } \\
\text { VAKIF ÜNivERSTTESi }\end{array}$ & $\begin{array}{r}\text { FS } \\
\text { FSM S }\end{array}$ & $\begin{array}{l}\text { M İlmî Araştırmalar Insan ve Toplum Bilimleri Dergisi } \\
\text { cholarly Studies Journal of Humanities and Social Sciences } \\
\text { Sayı/Number } 17 \text { Yıl/Year } 2021 \text { Bahar/Spring } \\
\text { C } 2021 \text { Fatih Sultan Mehmet Vakıf Üniversitesi }\end{array}$ & 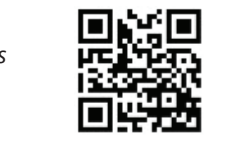 \\
\hline DOI: & & - & http://dergipark.org.tr/fsmia & http://dergi.fsm.edu.tr \\
\hline Araştırm & lesi / Research Article & - & Geliş Tarihi / Received: 16.04.2021 Kabul Tarihi / Accepted: 02.06.2021 & FSMIAD, 2021; (17): 35-54 \\
\hline
\end{tabular}

\title{
Haydarpaşa'da Gün Işığına Çıkarılan Abdülmecid Han Çeşmesi ve Sarnıcı ile Halid Ağa Çeşmesi Kitâbesi
}

\author{
Hasan Binay* \\ Zeynep Emel Ekim **
}

\section{Öz}

1839 yılında Sultan Abdülmecid'in ihya ettiği Halid Ağa Çeşmesi'nin adı değiştirilerek Abdülmecid Han Çeşmesi olmuştur. 1902 senesinde günümüzdeki Haydarpaşa'daki yerine taşınmış ve çeşme zamanla yol kotu altında kalmıştır. Haydarpaşa Tren İstasyonu alanında, "Marmaray Projesi Gebze-Halkalı Banliyö Hattı İyileştirmesi” kapsamında, İstanbul Arkeoloji Müzeleri denetiminde 2018 senesinde "Haydarpaşa Garı Arkeolojik Kazıları" başlatılmıştır. Kazı çalışmaları sırasında çeşmenin taşınmadan evvelki yerinden Halid Ağa Çeşmesi Kitâbesi bulunmuştur. Tıbbiye Köprüsü G1 ayağının inşası sırasında ise Haydarpaşa'daki mevcut yerinden Abdülmecid Han Çeşmesi ve Sarnıcı ortaya çıkarılmıştır. Tüm bu çalışmalar sayesinde gün ışığına çıkarılan bu eserler kültürel bir miras olarak kentsel dokuya tekrar kazandırılmıştır. Bu çalışmanın literatüre katkısı, çeşmenin yapım tarihinden günümüze kadar geçirdiği tüm değişimlerin belge ve haritalarla tespit edilmesidir. Çeşme, çağdaş örnekleri ile süsleme detayları açısından karşıllaştırılmış, ölçü

\footnotetext{
* Arkeolog/Sanat Tarihçi, İstanbul/Türkiye, hasanbny@gmail.com, orcid.org/0000-0002-93417993.

** Dr. Öğr. Üyesi, Fatih Sultan Mehmet Vakıf Üniversitesi Güzel Sanatlar Meslek Yüksek Okulu, İstanbul/Türkiye, zeeekim@fsm.edu.tr, orcid.org/0000-0003-1710-8731.
} 
ve yapısal özellikleri tanımlanarak araştırmacılara veri oluşturmuştur. Zamanla işlevini kaybeden çeşmenin yeniden ortaya çıkarılması ile koruma sorunları değerlendirilmiştir.

Anahtar Kelimeler: Haydarpaşa kazıları, çeşme, sarnıç, kitâbe.

\title{
Abdülmecid Han Fountain and Cistern and the Inscription of the Halid Ağa Fountain, Unearthed in Haydarpasha
}

\begin{abstract}
In 1839, the name of the Halid Ağa Fountain, which was restored by Sultan Abdülmecid, was changed into Abdülmecid Han Fountain. It was moved to its current location in Haydarpasha in 1902 and over the time the fountain remained below the road level . In the area of Haydarpaşa Train Station, "Haydarpasha Train Station Archaeological Excavations" was started in 2018 under the supervision of Istanbul Archeology Museums, within the scope of "Marmaray Project Gebze-Halkalı Suburban Line Improvement". During the excavations, the Halid Ağa Fountain Inscription was found in the place before the fountain was moved. During the construction of the T1bbiye Bridge G1 pillar, Abdülmecid Han Fountain and Cistern were unearthed from its current location in Haydarpaşa. Thanks to all these works, which were brought to light, were brought back to the urban fabric as a cultural heritage. The contribution of this study to the literature is to identify all the changes that the fountain has undergone from the date of its construction to the present day, with documents and maps. The fountain was compared with its contemporary examples in terms of ornamental details, its size, and the structural features were defined and data were created for researchers. Conservation problems were evaluated with the re-discovery of the fountain, which lost its function over time.
\end{abstract}

Keywords: Haydarpasha excavations, fountain, cistern, inscription. 


\section{Giriş}

Siyahi harem ağalarından Halid Ağa, Bağdat Valisi Ahmed Paşa’nın kızı Âdile Hatun'un dairesinde yetiştikten sonra İstanbul'da Sultan III. Ahmed'in kızlarından, Sadrazam Râgıb Paşa'nın hanımı Sâliha Sultan'ın konağında hizmet

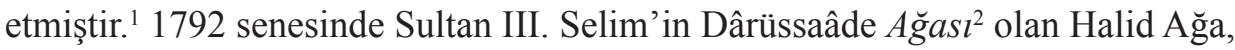
ilerleyen yıllarda Haremeyn-i Şerifeyn Evkaf Nazırı olmuştur. 29 Ağustos 1798 senesinde vefat eden, Halid Ağa'nın mezarı Eyüp'teki Mihrişah Valide Sultan Külliyesi’nin haziresinde bulunmaktadır. ${ }^{3}$

Halid Ağa'nın yaptırdı̆̆ı çeşmeler gibi Dârüssaâde Ağası olan Osman Ağa, Cafer Ağa ve İbrahim Ağa Kadıköy semtine mescitler yaptırmıştır. Halid Ağa Çeşmesi olarak adlandırılan bu çeşmelerin biri Haydarpaşa' da diğeri de Kadıköy civarında bulunmaktadır. ${ }^{4}$ Halid Ağa, 1794 senesinde kendi adına yapımına başlanan iki çeşmenin ve çeşmeler için gerekli su yollarının inşa faaliyetlerini Çamlıca eteklerinden su getirtmek suretiyle başlatmıştır. ${ }^{5}$ Çamlıca' daki üç kaynaktan beslenerek gelen suyun dağıtımı, Ali Paşa su yolları ile gerçekleşirken, 1923 senesinde su yollarının bozulmasından ötürü su gelememiştir. 1923 senesinde başlatılan çalışmalar ile Üçpınar mevkinde toplanan suyun, Uzunçayır, Kurbağalıdere, Söğütlüçeşme'den Altıyol ağzına getirilip mahallelere dağıtımı gerçekleştirilmiştir. ${ }^{6}$

1 Mücteba İlgürel, "Hâlid Ağa Çeşmesi”, Semavi Eyice Armağanı-İstanbul Yazıları, İstanbul, Türkiye Turing ve Otomobil Kurumu Yayınları, 1992, s. 300.

2 Tavâş̂ি (hadım) olan Harem Ağaları, Çelebi Sultan Mehmed zamanından itibaren Osmanlı sarayında da görevlendirildiler. Ağalar, beyaz hadımlar (akağalar) ve zenci hadımlar (karaağalar) olmak üzere iki ayrı sınıftan oluşmaktaydı. Ülkü Altındağ, "Dârüssaâde", İslâm Ansiklopedisi, cilt 9, İstanbul, Türkiye Diyanet Vakfi Yayınları, 1994, s. 1.

3 Mehmet Nermi Haskan, “Abdülmecid Han Çeşmesi”, Yüzyıllar Boyunca Üsküdar, cilt 3, İstanbul, Üsküdar Belediyesi Yayınları, 2001, s. 1035.

4 Kadıköy'deki Altıyol Meydanı'na çıkan ana caddenin solunda bulunan Halid Ağa Çeşmesi, Halid Ağa ve Nal sokakları ile sınırlanan kısımda bulunuyordu. Yanında bulunan Tanzimat döneminin kagir karakol binası 1930 senelerinde yıktırılır. Çeşme de 1940 senelerinde bulunduğu yerden alınarak yan sokağa taşınır. Tuğrası da kazınmıştır. Eyice, a.g.m., cilt 15, s. 282, 283.

514 Aralık 1794 tarihli keşif defterinde su yolu ile iki çeşmeye 26.929 kuruş ve 54 akçe harcama yapıldığı belirtilir. Semavi Eyice, "Hâlid Ağa Çeşmeleri", İslâm Ansiklopedisi, cilt 15, İstanbul, Türkiye Diyanet Vakfı Yayınları, 1997 s. 282; Darüssaade Ağası Halid Ağa tarafından Çamlıca da tahta köprü mahallinde kuyu ve kanallar kazılarak çıkarılan suyun, Ayrılık Çeşmesi`ne ve oradan Haydarpaşa ve Kadıköy〉deki iki çeşmeye getirilmesi için yapılan isale hattının masraflarına dair yapılan keşif ile Çamlıca〉da inşa edilen çeşme ve namazgâhın inşaat masrafları aynı defterde bulunmaktadır. TSMA. D. 10132, 1209 (1794).

6 Görkem Kızılkayak, (yay. haz.), Kadıköy Çeşmeleri-Kaynaktan Mahalleye Ab-ı Hayat, İstanbul, Kadıköy Belediyesi Yayınları, 2011, s. 40. 
Halid Ağa'nın Haydarpaşa'da bulunan ikinci çeşmesi, 1902 senesinde gar sahasından günümüzdeki yerine taşınmıştır. Çeşme, Kadıköy ilçesi, Rasim Paşa Mahallesi sınırlarında, 240 ada 16 parsel içinde yer almaktadır (Resim 1). İstanbul Arkeoloji Müzeleri denetiminde yürütülen Tıbbiye Köprüsü G1 ayağ1nın inşası sırasında çeşmenin ortaya çıkarılması için etrafının kazılması talebi, Kültür Varlıklarını Koruma Bölge Kurulu'na iletilmiştir. İstanbul V Numaralı Kültür Varlıklarını Koruma Bölge Kurulu'nun 19.07.2018 gün ve 5540 say1lı kararı ile Haydarpaşa Halid Ağa (Abdülmecid Han Çeşmesi) Çeşmesi'ndeki tespit kazısının tamamlanmasına karar verilmiştir. Buna istinaden İstanbul Arkeoloji Müzeleri denetiminde kazı yapılmış çeşmenin tamamı ve sarnıç bölümü de açığa çıkarılmıştır.

\section{Haydarpaşa Halid Ağa (Abdülmecid Han) Çeşmesi}

Günümüzde, çeşme, Tıbbiye Caddesi (Kadıköy-Haydarpaşa Rıhtım Caddesi) üzerinde, Kadıköy Toplum Sağlığı Merkezi ${ }^{7}$ binasının bahçe duvarı önünde ve Haydarpaşa Köprüsü'nün Üsküdar tarafında kalan ayağının başladığı yerde bulunmaktadır (Resim 2).

Haydarpaşa Köprüsü 1930 senelerinde yapılırken çeşme üst kısmına kadar toprak altında kalmıştır. Bir dönem önünde bir çukur açılarak bir dereceye kadar meydana çıkarılmışsa da önü tekrar dolmaya başlamıştır ${ }^{8}$ (Resim 3). İstanbul Arkeoloji Müzeleri tarafından, Haydarpaşa Gar sahası içinde başlatılan kazı çalışmalarına kadar çeşme toprağa gömülü bir şekilde durmuş̧tur (Resim 4 ve 5).

Bazı kaynaklarda çeşmenin adı, "Halid Ağa" bazılarında ise "Abdülmecid Han Çeşmesi” olarak geçmektedir. Sultan Abdülmecid, Halid Ağa`nın su yolları ile birlikte Kadıköy〉deki çeşmesini tamir ettirirken, Haydarpaşa' daki Halid Ağa Çeşmesi'nin yeniden inşaa faaliyetlerini 1835 senesinde başlatır. ${ }^{9} \mathrm{Bu}$ yüzden çeşme "Abdülmecid Han Çeşmesi” olarak da anılmıştır. Çeşmenin 1902 senesinde günümüzdeki yerine taşınması ile su yolu değişmiş ve çeşme suyunu bir müddet Seyyid Ahmet Deresi'nden almıştır. ${ }^{10}$

7 Eski Dârü'l-Eytâm (Yetimhâne) olan bu bina sırasıyla Emrâz-1 Sâriye Hastahanesi (Bulaş1c1 Hastalıklar- İntaniye), Verem Hastahanesi ve Ticaret Lisesi, Numune Hastanesi Diş Kliniği olarak kullanılmıştır. İbrahim Hilmi Tanışık, İstanbul Çeşmeleri II, Beyoğlu ve Üsküdar Cihetleri, İstanbul, Maarif Matbaası, 1945, s. 436.

8 Eyice, a.g.m., cilt 15, s. 283.

9 BOA. HAT. 1591/62, 1250/1835.

10 Seyyid Ahmet Deresi'ndeki İhsan Bey tarlasından çeşmeye gelen suyun yolları harap olunca İranlılar Havuzu'ndan çeşmenin suyu temin edilmiştir. Kızılkayak, a.g.e., s. 40. 
1839 y1lında Sultan Abdülmecid tarafından çeşme yenilenirken bir de kitâbe konulur. Şair Zîver Paşa ${ }^{11}$ tarafından yazılan kitâbede, Sultan Abdülmecid'in 1839 senesinde çeşmeyi yeniden yaptırdığ 1 ifade edilir. Ancak bu çeşmenin kitâbesi, bahçedeki tarihi yapı İntaniye Hastahanesi olarak kullanılıyor iken hastahanenin bir görevlisi tarafından 1930 senelerinde kırdırılmak suretiyle yok edilmiştir. ${ }^{12}$ Türkiye Cumhuriyeti'nde, mebânî-i resmiye ve milliye üzerindeki tuğra ve methiyelerin kaldırılması hakkındaki 1057 sayılı kanun, 15 Haziran 1927 günkü ve 608 sayılı Resmi Gazete'de yayımlanarak yürürlüğe girer. Beş maddeden oluşan bu kanun uygulanırken tuğralar ve kitâbeler kırdırılmış, kazınmış veya kapatılmıştır. ${ }^{13}$

Kitâbe, yok edilmeden önce Mehmet Raif tarafından okunarak kaydedilmiştir ${ }^{14}$ :

Çeşme-sâr-1 mâdelet Abdülmecid Hanın Hüdâ/ Feyz-i zâtın kıldı bâdî-i hayat-1 kâinât/ Hân Selîm-i sâlisin Dârüssaâde ağası /Hâlid Ağa nâm deryâ-mekremet bir pâk-zât / Yapdırub bu çeşmeyi sonra harâb olmuş idi / Görüp ol şâh-1 cihân ihyâya kıldı iltifât/ Cûybâr-1 şevket u iclâlin ol şehinşâhın/ Haşre dek kılsun Hüdâ reşk-âver-i Şatt u Fırat/ Cevher-i tarih-i Ziver suyunu bulsa sezâ/ Kıldı Han-1 Abdülmecid icrâ güzel ayn-i hayat/Sene 1255 (1839)

\section{Haydarpaşa'daki Abdülmecid Han Çeşmesi’nin Mimarisi ve Süsleme Özellikleri}

Çeşme dikdörtgen planlıdır ve Marmara mermerinden yapılmıştır. Genişliği 2.52 metredir. Açığa çıkarılan kurna alt noktasından ölçülebilen yüksekliği yakla-

11 Sultan II. Mahmud ve Abdülmecid Dönemi'nin başarılı şairlerinden biri olan Zîver Paşa, tarih düşürme konusunda üstad olup, divan şiirinin inceliklerini de şiirlerinde ustalıkla kullanmıştır. Sultan II. Mahmud ve Abdülmecid Dönemleri'nde yapılan birçok eserin tarih manzumeleri ona aittir. Hasan Aksoy, "Zîver Paşa”, İslâm Ansiklopedisi, cilt 44, İstanbul, Türkiye Diyanet Vakfı Yayınları, 2013, s. 474; Halid Ağa’nın Kadıköy'de bulunan üçüzlü çeşmesinin, ortada yer alan, ikinci kitâbesi beş beyitlik bir tamir kitâbesi olup Şair Zîver Bey tarafından düzenlenmiştir. Eyice, a.g.m., cilt 15, s. 283.

12 Eyice, a.g.m., cilt 15, s. 283.

13 Bu kanun ile kapatılan kitâbelerden biri de Çengelköy Havuzbası Mektebi'nin kitâbesidir. Zeynep Emel Ekim, “Çengelköy Havuzbaşı Mektebi’nin Gün Yüzüne Çıkan Kitâbesi, Üsküdar'ın Kayıp Kitâbeleri”, Üsküdar Kültür, Sanat ve Medeniyet Dergisi, sayı 9, Üsküdar Belediyesi Yayınları, Aralık 2019, s. 134-135.

14 Kolağası Mehmet Râ'if, Mir'ât-ı İstanbul-Asya Yakası, haz. Günay Kut - Hatice Aynur, cilt 1, İstanbul, Çelik Gülersoy Vakfı Yayınları, 1996, s. 59-60.

15 Mehmet Raif okuduğu kitâbenin hat türünden bahsetmemiştir. Tarih beytinin olduğu son mısrada ebced hesabına göre tarih düşürülmüştür. 
şık 3,24 m iken seki üst noktasından yüksekliği 2.57 metredir. Mermerlerde kısmi yüzey kayıpları çatlaklar ve yüzeylerde kirlenme mevcuttur.

Çeşmenin alınlık kısmında ortada yer alan dikdörtgen kitâbe yaklaşık 1.32x $0,59 \mathrm{~m}$ boyutlarındadır ve günümüze ulaşamamıştır. Kitâbenin yer aldığı bölüm üzerinde yivli profiller halinde silme yer almaktadır. Saçak bulunmamaktadır ve düz çatılıdır. Kitâbenin sağ ve solundaki lir motifli çerçeveler $0.39 \times 0.59 \mathrm{~m}$ boyutlarındadır. Çeşmenin musluğunun bulunduğu ayna taşı ve üzerinde yer alan niş uzun olarak yekpare mermerden yapılmıştır ve 1.18x1.36 m boyutlarındadır. Ayna taşı, basık bir kemer ile sonlanmaktadır (Resim 6).

Çeşmenin sol üstündeki ikinci panel üzerine bir adet maşrapa asma amaciyla metal kenet yapılmıştır. Ayna taşının iki yanında ve çeşmenin dış cephesinde $0.12 \mathrm{~m}$ genişliğinde ve $1.60 \mathrm{~m}$ yüksekliğinde dikdörtgen pilastrlar bulunmaktadır. Sağ ve solda ikişer adet olan bu pilastrların iç bükey sade kaideleri vardır. $\mathrm{Bu}$ bantların arasında yüzey derinliği fazla olmayan, sağ ve solda dörder adet kartuş yerleştirilmiştir. Bu kartuşların içerisinde fiyonklu, yapraklı çiçek demetleri bulunmaktadır. Çeşmenin kurnası dörtgen planlıdır ve yaklaşık $4.99 \times 0.58 \mathrm{~m}$ boyutlarındadır. Ortada kurnanın iki yanında yaklaşık $0.82 \times 0.64 \mathrm{~m}$ boyutlarında mermer seki yer alır. Çeşmenin kitâbesinin olduğu kısmın arka tarafında da iki yanda aynı motifler bulunmaktadır. Sağında ve solunda iki mermer pilastr bulunmaktadır (Resim 7).

Süslemeler dönemin ampir, rokoko ve barok üslubu etkilerini taşımaktadır. Çeşmenin ön yüzünde günümüze gelemeyen kitâbenin sağ ve soluna birbirinin aynı simetrik lir motifleri tasarlanmıştır ${ }^{16}$ Yivli konik bir kaide üzerinde duran lirin tellerinin altında ve üstünde birer altıgen yıldız motifi bulunmaktadır. Lirin en tepesi bir yaprak motifi ile sonlanır. Kolları iki yana açılan lirin uçları volüt şeklindedir. Volütlerin iki yanında dalgalı kurdele motifi sarkmış olarak verilmiştir. Bu kurdelenin biçimi durağan motife bir hareket sağlamıştır (Resim 8).

Çeşmenin musluğunun bulunduğu ayna taşı ve üzerinde yer alan niş yekpare mermerden yapılmıştır. Musluğun üzerinde sola kıvrılmış bir adet içinde inci bulunan istiridye kabuğu bulunmaktadır. İstiridye kabuğunun iki yanından ç1kan kabartma yivler, köşelerinde simetrik olarak yer alan palmetlerle beraber çeşmenin nişini yanlarda düğüm motifi yapacak şekilde sarmıştır. Bu kabartma

16 Lir motifi nadir görülen bir motiftir. Özellikle Sultan Abdülmecid Dönemi'nde örneklerine rastlanılır. Küçüksu Kasrı'nın zemin katta yer alan odasının tavanlarında flüt, arp ve benzeri müzik aletlerinin kalemişi motifleri görülür. Nesrin Taşer, "Istanbul'da Ihlamur ve Küçüksu Kasırları", (Yayımlanmamış Yüksek Lisans Tezi), cilt I, Gazi Üniversitesi SBE Sanat Tarihi Anabilim Dalı, Ankara, 2008, s. 87. 
yivler, musluk üzerinde bulunan istiridye kabuğu ile aynı dikey eksende yer almakta olan deniz kabuğu ile birleşir. Bu bir çeşit oldukça sadeleştirilmiş sarma dal sayılabilir. Bu yumuşak hatlı, yuvarlatılmış yivler kemerle uyum sağlayarak iç bükey derinlik kazandırmıştır. Dekoratif kemer üzerinde yer alan geniş yuvarlak hatlı bant ile köşeler birbirinden ayrılmıştır. Kemer üstündeki köşeliklerde, birbirinin aynı fiyonklu, yapraklı çiçek demetleri yapılmıştır. Bu süslemeler, kartuşlara ayırma şekli ve deniz kabuklularının kullanılması Rokoko üslubundadır ve sadeleştirilerek kullanılmıştır. Ayna taşının iki yanında sağda ve solda olmak üzere beş adet olan içi boş kartuşlar barok tarzda kıvrımlı kesilmişlerdir. Ayna taşının iki yanında dikdörtgen pilastrlar bulunmaktadır. Esas düzene ait bu pilastrlar kütlesel formdadır. Sağ ve solda ikişer adet olan bu pilastrların iç bükey sade kaideleri vardır. Bu pilastrlar arasında yüzey derinliği fazla olmayan, sağ ve solda dörder adet Barok tarzı kartuşlar yerleştirilmiştir. Bu kartuşların içerisinde natüralist bir düzende yer alan fiyonklu, yapraklı çiçek demetleri bulunmaktadır. Demetlerde bulunan bazı çiçek motifleri boynunu bükmüş olarak gösterilmiştir. Her çiçek demeti karşısında bulunan kartuştaki çiçek demeti ile aynı formda yapilmıştır (Resim 9).

Abdülmecid Han Çeşmesi'nin, çeşme aynasındaki süsleme özelliklerinin çok benzer bir örneğini 1793 senesinde yapılan Çamlıca Meryem Kadın Çeşmesi’nde görülmektedir (Resim 10). Aynı zamanda Meryem Kadın Çeşmesi’nin kitâbesinin her iki yanında Sultan III. Selim'in tuğrasının etrafında, Abdülmecid Han Çeşmesi'ndeki kartuşların içerisinde yer alan çiçeklerin benzer bir örneği görülür (Resim 11).

Çeşmenin kurnası dörtgen planlı ve sade yapıdadır. Kurnanın iki yanında, dörtgen planlı ve sade yapıda pilastr bantları ve kartuşların oturduğu sekiler bulunmaktadır.

Çeşmenin arka yüzünde, ortadaki bölümde, çerçeve içinde çapraz bir şekilde yerleştirilmiş iki kubur kurdelalara dolanmıştır. Bu kuburların içindeki ok demetlerinin sapları başak tanesi gibi gözükmektedir. Bu ok demetleri Sultan II. Mahmud Haziresi'nde yer alan bir çeşmede de görülür (Resim 12). Bu tür süslemelerin örneğine ampir üslupta çok rastlanılmaktadır. Örneğin Maçka'daki Bezm-i Âlem Vâlide Sultan Çeşmesi'nin çeşme aynasında çapraz bir şekilde gelen meşaleler kurdelalar içindedir. Abdülmecid Han Çeşmesi'nin ön yüzünde yer alan lir motifleri arka yüzünde de ortada yer alan çerçevenin sağ ve solunda aynı düzenleme ile ele alınmıştır (Resim 13). 


\section{Haydarpaşa'daki Abdülmecid Han Çeşmesi'nin Sarnıcı}

Yapılan kazılarda çeşmenin arka tarafinda, tuğla tonozlu su sarnıcı açığa çıkarılmıştır. Sarnıç yaklaşık $4.53 \times 2.23$ m boyutlarında dikdörtgen yapılı ve kagir duvarlıdır. Duvarlarda çimento esaslı sıva görülür. Zemin şap kaplamalı olup bozulmalar mevcuttur. Sarnıcın kuzey duvarı üzerinde "1902" tarihi görülür (Resim 14). Zemin kotu en alt noktası +14.54 kotunda tavan, ise +15.68 kotundadır. Yüksekliği 1.40 metredir. Yaklaşık $0.71 \times 0.42 \mathrm{~m}$ boyutlarında tepe açıklığı bulunmaktadır. Sarnıç üstü kireç harçlıdır (Resim 15). Kaidesi moloz taş örgülüdür.

\section{Arkeolojik Kazılar Sonucunda Bulunan Haydarpaşa'daki Halid Ağa Çeşmesi’nin İlk Kitâbesi}

İstanbul Arkeoloji Müzeleri tarafindan Haydarpaşa Gar sahası içinde yapılan kazı çalışmalarında ortaya çıkarılmış olan çeşmenin ilk kitâbesi, ilk inşa olduğu yerin civarında bulunmuş ve kitâbeye 1796/97 tarihi düşülmüsstür. Kitâbede "Sâhibü'l-Hayrât Dârüssaâde-i şerife ağası Hazreti Hâlid Ağa 1211" yazmaktadır (Resim 16).

Eskiden Kadıköy civarındaki çayırlardan en çok Haydarpaşa, Uzunçayır, Kuşdili ve Yoğurtçu çayırlarına halk rağbet göstermekteydi. ${ }^{17}$ Halid Ağa Çeşmesi’nin taşınmadan evvelki ilk yapıldığı yer Haydarpaşa Çayırı'nda bulunmakta idi. Ayrılık Çeşmesi gibi Halid Ağa Çeşmesi'si de Haydarpaşa çayırında kullanılan bir menzil çeşmesidir. Haydarpaşa İskelesi eskiden beri bilindiğinden, bu civarda Halid Ağa Menzili'nden evvel olan bir iskele menzili de yapılmış olmalıydı. ${ }^{18}$ Fakat Haydarpaşa yöresinde 1873 senesinde İstanbul-İzmit demiryolu hattının hizmete başlaması ile çayır adeta demiryolu hattı ile ikiye bölünmüş ve ilk gar binası inşa edilmiştir. 1899-1903 yılları arasında deniz doldurularak gar için gerekli olan depolama alanları, iki silo ve mendireğin yapımı ile bir liman oluşturulur. ${ }^{19}$

Çeşmenin etrafında demir parmaklıklı bir de namazgâhın varlığından da bahsedilmektedir. ${ }^{20} 1902$ yılında tren hatlarının geçmesi nedeniyle çeşme ilk ye-

17 Kizılkayak, a.g.e., s. 22.

18 Muammer Kemal Özergin, "Üsküdar-Bostancıbaşı Derbendi Güzergâhı Mimarî Eserlerinin Kitabeleri”, Tarih Dergisi, cilt 9, say1 13, İstanbul Edebiyat Fakültesi Basımevi, 1958, s. 115-116.

19 M. Rıfat Akbulut, "Haydarpaşa", Dünden Bugüne İstanbul Ansiklopedisi, cilt 1, İstanbul, Türkiye Ekonomik ve Toplumsal Tarih Vakfi, 2003, s. 28.

20 Mehmet Râ'if, a.g.e., s. 59; Bu civarda Haydar Baba türbesi yanında Mehmet Efendi’nin, III. Mustafa'nın cebehane ocağı memuru babası Ömer Efendi için yaptırdığı "Haydar Paşa Namazgâh" bulunmakta idi. Yol genişletmesi sonucunda namazgâh yok edilmiş türbe de tamir edilmiştir. İbrahim Hakk1, Konyalı, Âbideleri ve Kitâbeleriyle Üsküdar Tarihi, cilt I, İstanbul, Türkiye Yeşilay Cemiyeti Yayınları, 1976, 410. 
rinden, 1872 yılında inşaa edilen ilk gar binası karşısından alınarak günümüzde bulunan Haydarpaşa Köprüsü'ndeki noktaya taşınmıştır. Osmanlı arşiv belgelerinde çeşme ve namazgâhın 1902 tarihli şimdiki yerine taşınmasına dair yazışma ve harita bulunmaktadır. Bu taşımanın nereden nereye yapılacağını gösteren 1902 yılına Emlâk-1 Hümâyun' dan olan “Haydarpaşa çayırı, Haydarpaşa İstasyonu ve Haydarpaşa İskelesi” civarını gösteren kroki üzerinde aynı zamanda gar ve civarındaki mevcut yapıları da görmek mümkündür. ${ }^{21} \mathrm{Bu}$ yazışmalara göre (şimendifer istasyonu) demiryolu içinde kalan çeşmenin demiryolunu işleten şirket tarafından hat dışına taşınmasına dönük talebi olumlu karşılanmıştır. Çeşme ile namazgâhın, Haydarpaşa Hastahanesi Bağçesi'nin yol üstünde (tarik-i aşırı) köşesinde bulunan alana nakli uygun görülerek, çeşme günümüzde bulunan yerine taşınmışı ır ${ }^{22}$ (Resim 17). Fakat belgelerde namazgâhın taşınmasından bahsedildiği halde günümüzdeki taşınan yerinde ve eski yerinde namazgâhın herhangi bir izine rastlanılmamıştır.

\section{Sonuç}

Abdülmecid Han Çeşmesi için ikincil kaynaklarda çeşmenin toprak altında kaldığı, eski kitâbesi için de kayıp olduğu ifadesi geçmektedir. Marmaray Projesi'nin Haydarpaşa Gar sahası modernizasyon çalışmaları kapsamında yürütülen Tıbbıye Köprüsü'nü yenileme çalışmalarında, İstanbul V Numaralı Kültür Varlıklarını Koruma Bölge Kurulu tarafından verilen karar doğrultusunda, İstanbul Arkeoloji Müzeleri tarafindan gerçekleştirilen kazılar sırasında açığa çıkan Abdülmecid Han Çeşmesi, sarnıcı ve eski kitâbesi kültür ve sanat tarihimize kazandırılmıştır. Fakat eserlerin gün 1şığına çıkması beraberinde koruma sorunlarını da getirmektedir.

Çeşme ve sarnıcın, eski yerine taşınması veya yerinde korunması şeklinde öneriler doğrultusunda hazırlanacak olan restorasyon projesi, fiziksel ve sosyokültürel açıdan sürdürülebilirliğini sağlamalıdır. Taşınması durumunda çeşme ve sarnıcın bütüncül ele alınarak hazırlanan malzeme raporları gibi bilimsel raporların, yapıların taşınmaya olan uygunluğunu destekler nitelikte olması gerekmektedir. Çeşme ve sarnıcın taşındığı çevrenin analizi proje ve raporlara yansıtılmalıdır. Raporların içeriğinde örnek olarak dünyadan ve ülkemizden taşınarak korunmuş eserlere yer verilmelidir.

Çeşme ve sarnıç günümüzde yoğun trafik akışının olduğu yol kotu altındadır. Yapıların mevcut yerinde korunması için uygunluğu durumunda yüksek kotlara

21 BOA. PLK. p. 389. 1320/1902.

22 BOA. Y. MTV. 230/7, 3 Safer 1320/ 12 May1s 1902. 
taşınması gerekecektir. Aksi halde zamanla gün ışığına çıkarılan yapılar moloz ve çöplerle dolarak tekrar toprağa gömülecek hafizalarımızdan silinecektir. Yap1ların yol kotuna taşınması durumunda halk tarafindan ulaşılabilir ve algılanabilir hale gelecek olan yapılar kent kimliğine katkı sağlayacaktır. Yol kotuna yükseltilecek yapıların çevre düzenleme projelerinin de hazırlanması kentsel dokuya kazandırılması sürecini hızlandıracaktır. Tüm bu çalışmalar doğrultusunda İstanbul kültür yaşamına dahil olacak bu eserlerin gelecek nesillere aktarılması ve kültür mirasımız olarak koruma politikalarının geliştirilmesi gerekmektedir. 


\section{Kaynakça}

Akbulut, M. Rıfat, "Haydarpaşa", Dünden Bugüne İstanbul Ansiklopedisi, cilt 1, İstanbul, Türkiye Ekonomik ve Toplumsal Tarih Vakfi, 2003.

Aksoy, Hasan, "Zîver Paşa”, İslâm Ansiklopedisi, cilt 44, İstanbul, Türkiye Diyanet Vakfi Yayınları, 2013.

Altındağ, Ülkü, "Dârüssaâde", İslâm Ansiklopedisi, cilt 9, İstanbul, Türkiye Diyanet Vakfi Yayınları, 1994.

Ekim, Zeynep Emel, “Çengelköy Havuzbaşı Mektebi’nin Gün Yüzüne Ç1kan Kitâbesi, Üsküdar'ın Kayıp Kitâbeleri”, Üsküdar Kültür, Sanat ve Medeniyet Dergisi, say1 9, Üsküdar Belediyesi Yayınları, Aralık 2019.

Eyice, Semavi, "Hâlid Ağa Çeşmeleri”, İslâm Ansiklopedisi, cilt 15, İstanbul, Türkiye Diyanet Vakfı Yayınları, 1997.

Haskan, Mehmet Mermi, “Abdülmecit Han Çeşmesi”, Yüzyıllar Boyunca Üsküdar, cilt 3, İstanbul, Üsküdar Belediyesi Yayınları, 2001.

İlgürel, Mücteba, "Hâlid Ağa Çeşmesi”, Semavi Eyice Armağanı-İstanbul Yazıları, İstanbul, Türkiye Turing ve Otomobil Kurumu Yayınları, 1992.

Kızılkayak, Görkem, (yay. haz.), Kadıköy Çeşmeleri-Kaynaktan Mahalleye Ab-ı Hayat, İstanbul, Kadıköy Belediyesi Yayınları, 2011.

Kolağası Mehmet Râ'if, Mir'ât-ı İstanbul-Asya Yakası, haz. Günay Kut - Hatice Aynur, cilt 1, İstanbul, Çelik Gülersoy Vakfı Yayınları, 1996.

Konyalı, İbrahim Hakk1, Âbideleri ve Kitâbeleriyle Üsküdar Tarihi, cilt I, İstanbul, Türkiye Yeşilay Cemiyeti Yayınları, 1976.

Özergin, Muammer Kemal, "Üsküdar-Bostancıbaşı Derbendi Güzergâhı Mimarî Eserlerinin Kitabeleri”, Tarih Dergisi, cilt 9, say1 13, İstanbul Edebiyat Fakültesi Basımevi, 1958.

Tanışık, İbrahim Hilmi, İstanbul Çeşmeleri II, Beyoğlu ve Üsküdar Cihetleri, İstanbul, Maarif Matbaas1, 1945.

Taşer, Nesrin, "İstanbul'da Ihlamur ve Küçüksu Kasırlarl", (Yayımlanmamış Yüksek Lisans Tezi), cilt I, Gazi Üniversitesi SBE Sanat Tarihi Anabilim Dal1, Ankara, 2008.

\section{Arşivler}

Başbakanlık Osmanlı Arşivi

BOA. HAT. 1591/62, 1250/1835. 
BOA. Y. MTV. 230/7, 3 Safer 1320/ 12 Mayıs 1902.

BOA. PLK. p. 389. 1320/1902.

TSMA. D. 10132, 1209 (1794)

Arkeo Teknik Mimarlık ve Restorasyon Şirketi Arşivi

Arkeoloji Müzeleri Müdürlüğü Arşivi

\section{İnternet Kaynakları}

Google Earth

kulturenvanteri.com (Erişim Tarihi 10 Ocak 2021)

\section{Teşekkür}

$\mathrm{Bu}$ makalenin hazırlanmasında resmi izinlerin sağlanması hususunda destek olan Haydarpaşa Arkeolojik Kazıları başkanı ve İstanbul Arkeoloji Müzeleri Müdürü arkeolog Sayın Rahmi Asal'a, kazı çalışmalarında görev alan müze uzmanlarına ve çeşme çizimlerini yapan Arkeo teknik mimarlık ekibine, projede emeği geçen Ulaştırma Bakanlığı ve Devlet Demiryolları personeline teşekkür ederiz.

\section{Resimler}

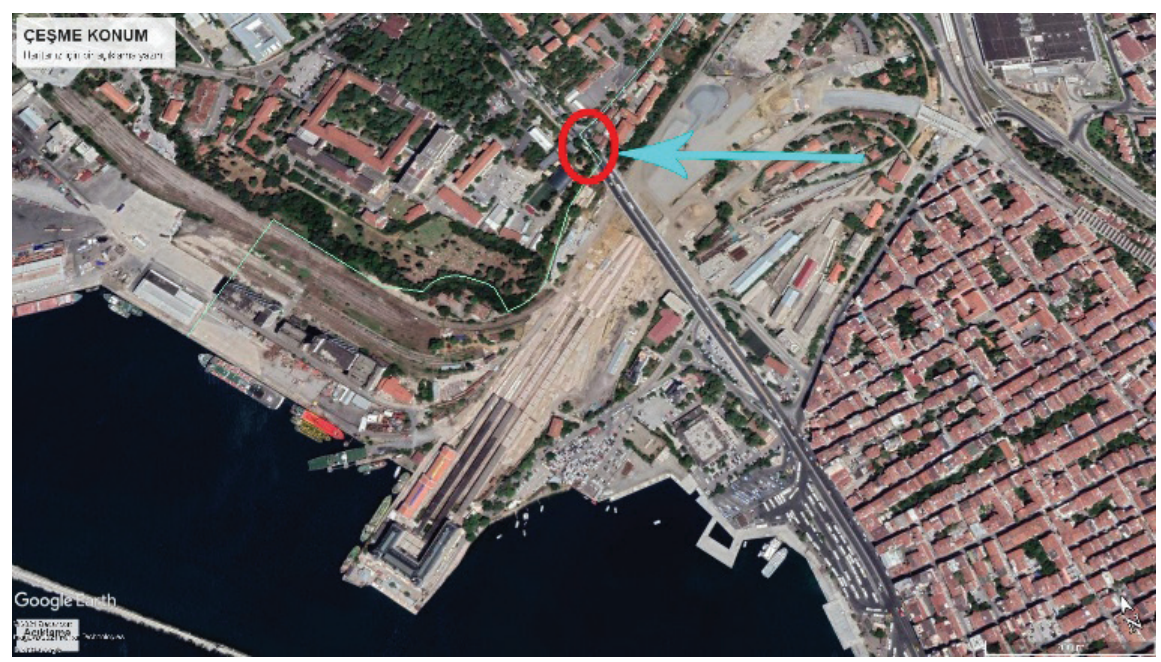

Resim 1. Abdülmecid Han Çeşmesi’nin hava fotoğrafından güncel konumu, google earth 


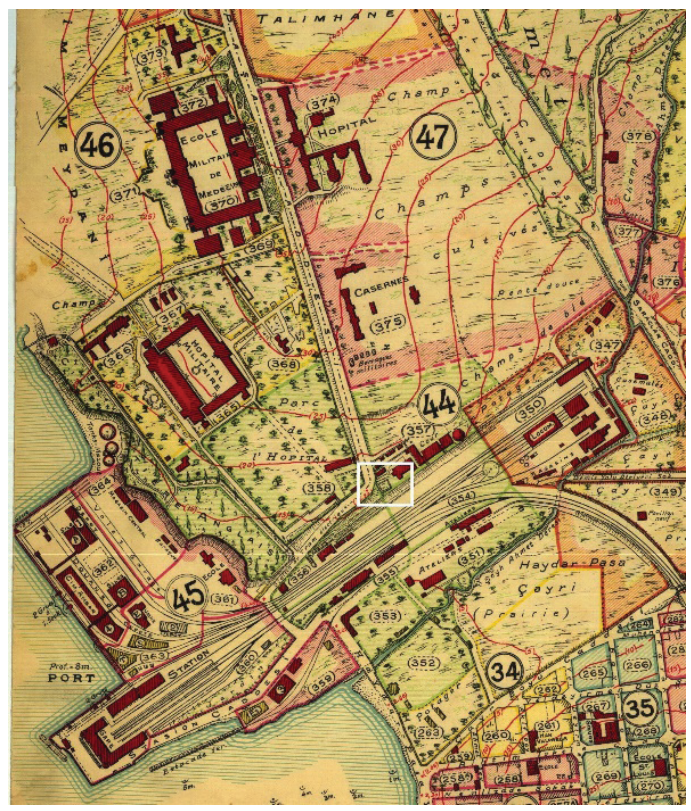

Resim 2. Pervititch Sigorta Haritası'ndaki Abdülmecid Han Çeşmesi'nin taşınmadan sonraki konumu

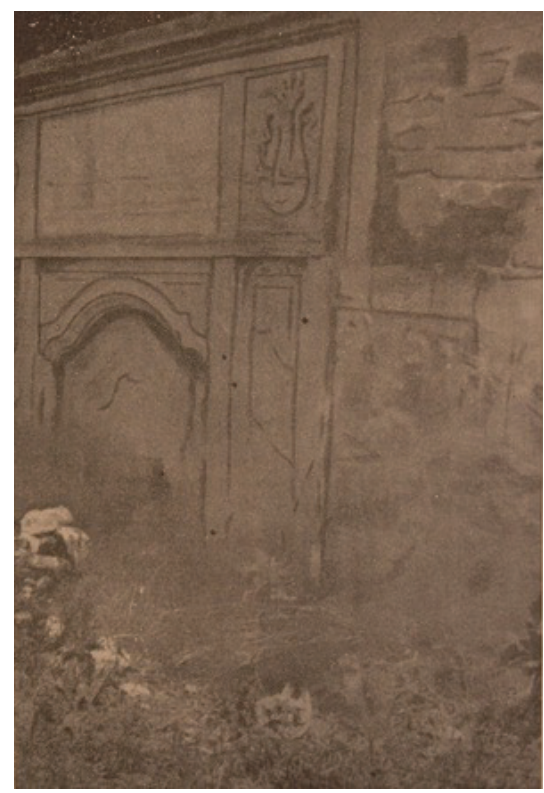

Resim 3. Abdülmecid Han Çeşmesi'nin eski bir fotoğrafı (İbrahim Hilmi Tanışık, İstanbul Çeşmeleri II, Beyoğlu ve Üsküdar Cihetleri, s. 437) 


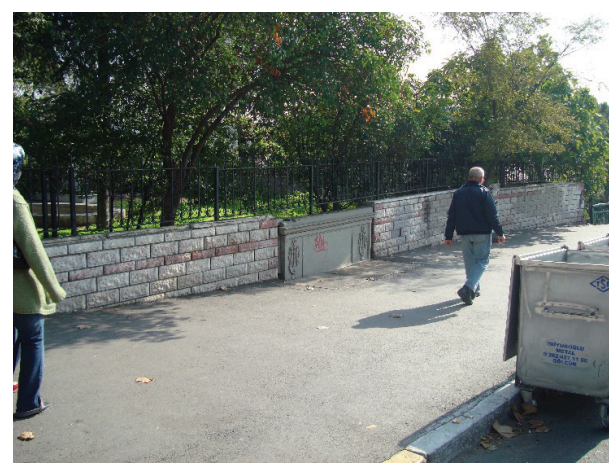

Resim 4. Abdülmecid Han Çeşmesi taç kısmının kazı öncesi cepheden bir görünümü, 2008, (Zeynep Emel Ekim Arşivi)

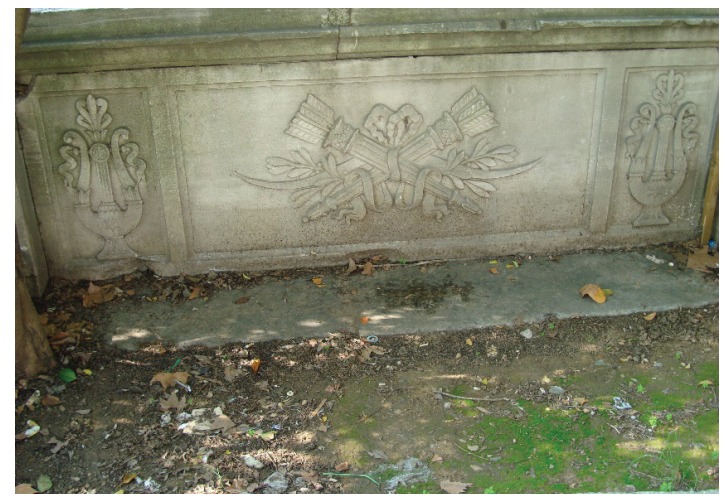

Resim 5. Abdülmecid Han Çeşmesi taç kısmının kazı öncesi sarnıç yönünden bir görünümü, 2008, (Zeynep Emel Ekim Arşivi)

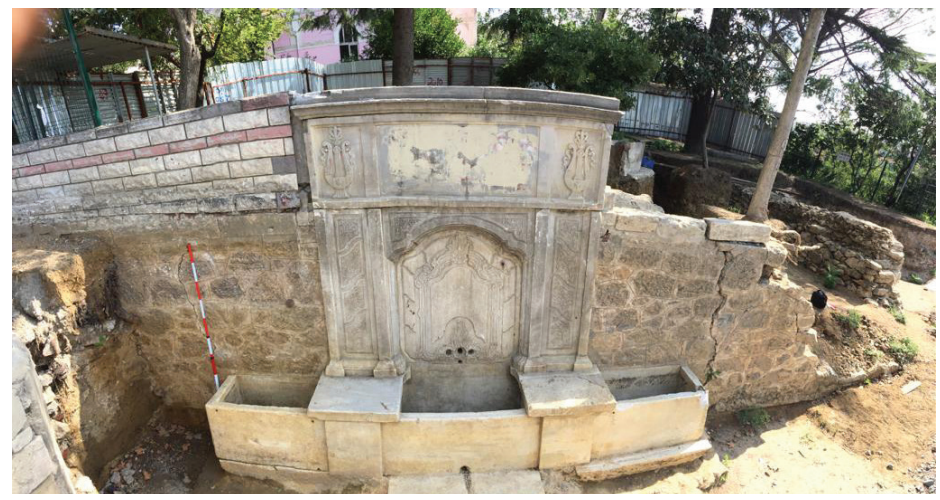

Resim 6. Abdülmecid Han Çeşmesi'nin kazılarla ortaya çıkan cephe görünümü, Arkeo Teknik Mimarlık ve Restorasyon Şirketi Arşivi 


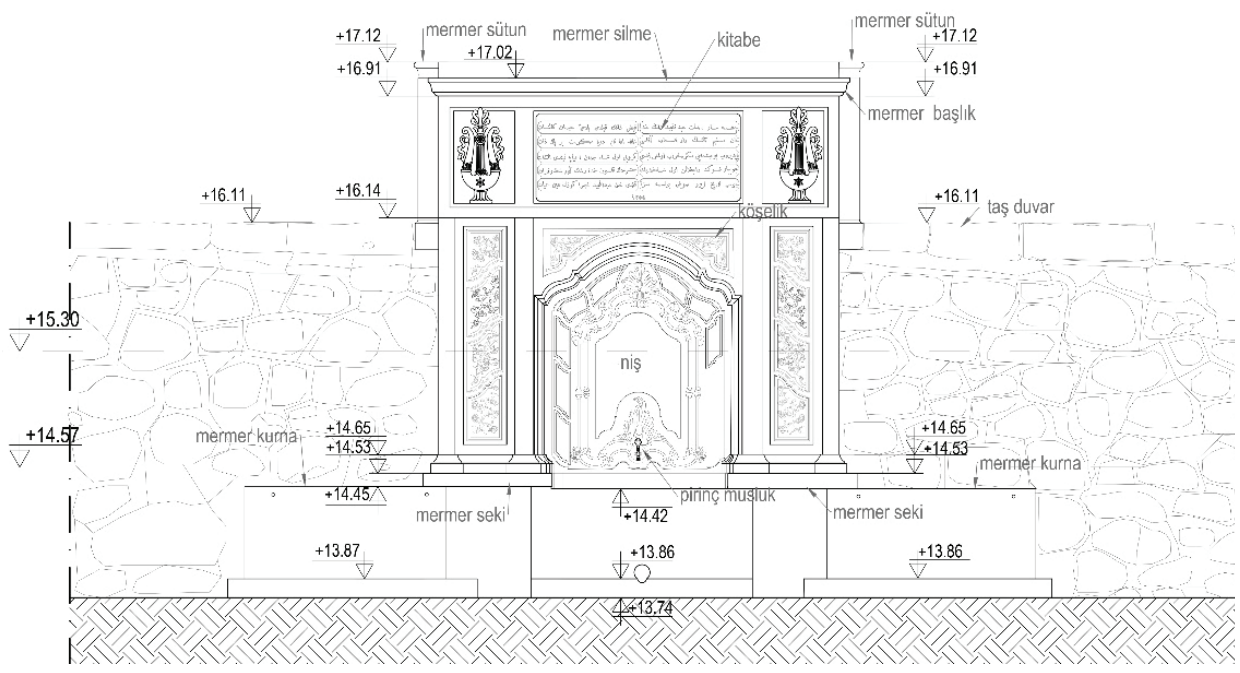

Resim 7. Abdülmecid Han Çeşmesi cephe restitüsyonu, Arkeo Teknik Mimarlık ve Restorasyon Şirketi Arşivi

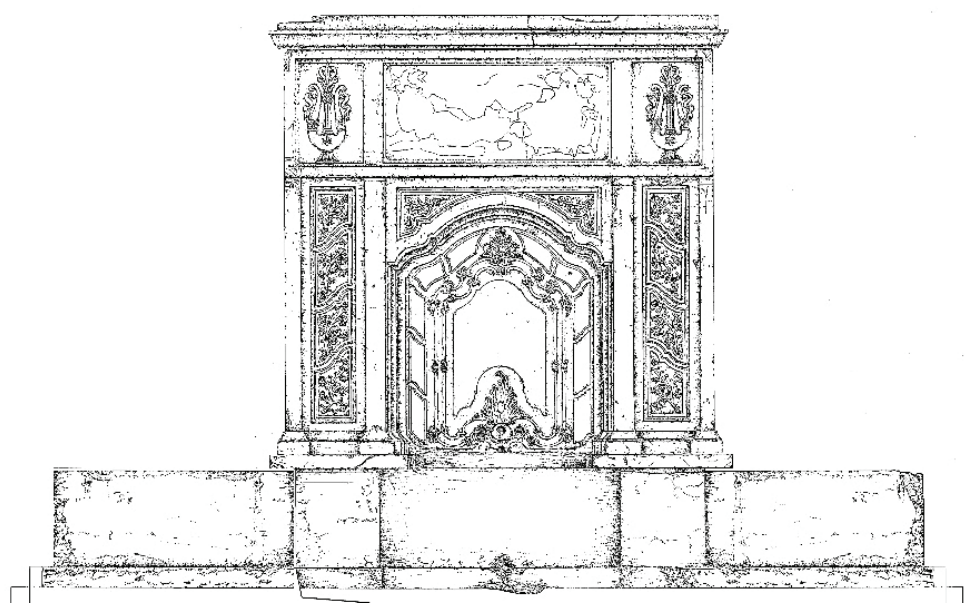

Resim 8. Abdülmecid Han Çeşmesi'nin el çizimi, Arkeo Teknik Mimarlık ve Restorasyon Şirketi Arşivi 


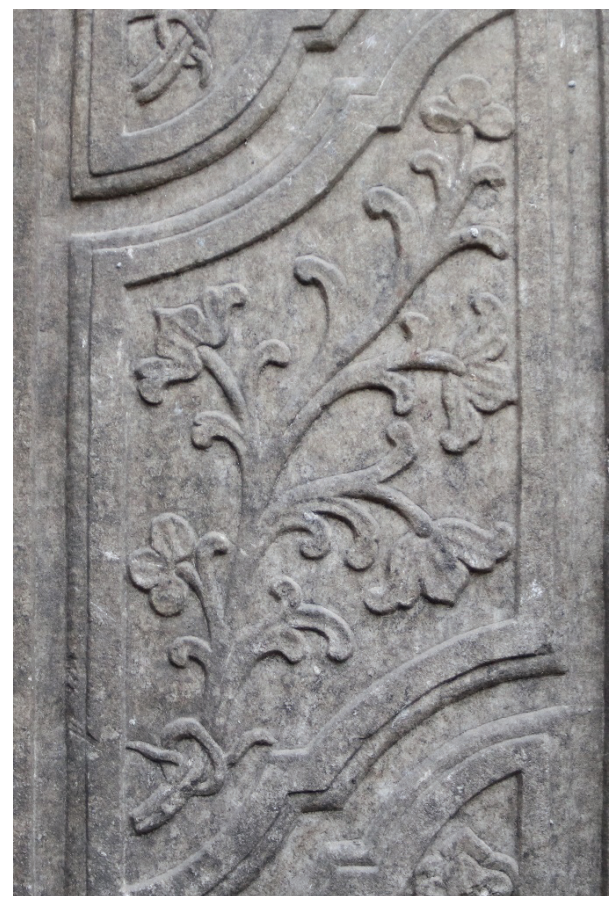

Resim 9. Abdülmecid Han Çeşmesi’nin ön yüzündeki kartuş içi bezeme detayı, Arkeo Teknik Mimarlık ve Restorasyon Şirketi Arşivi

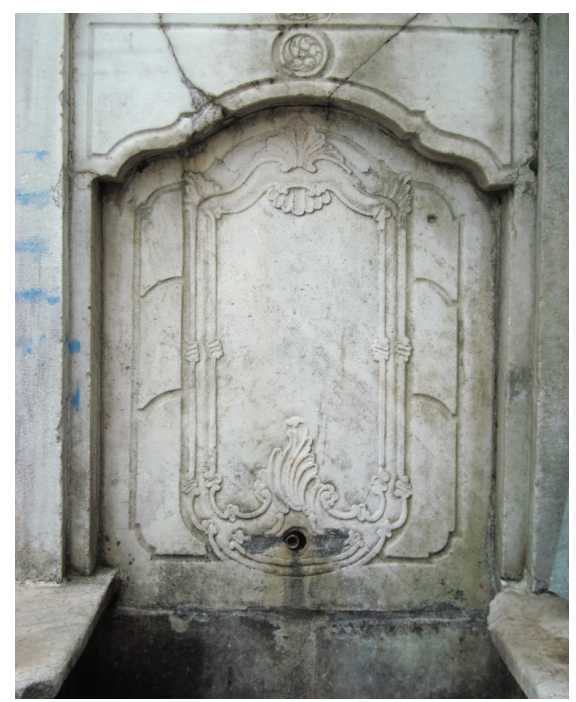

Resim 10. Meryem Kadın Çesmesi ayna taş1, 2008, (Zeynep Emel Ekim Arşivi) 


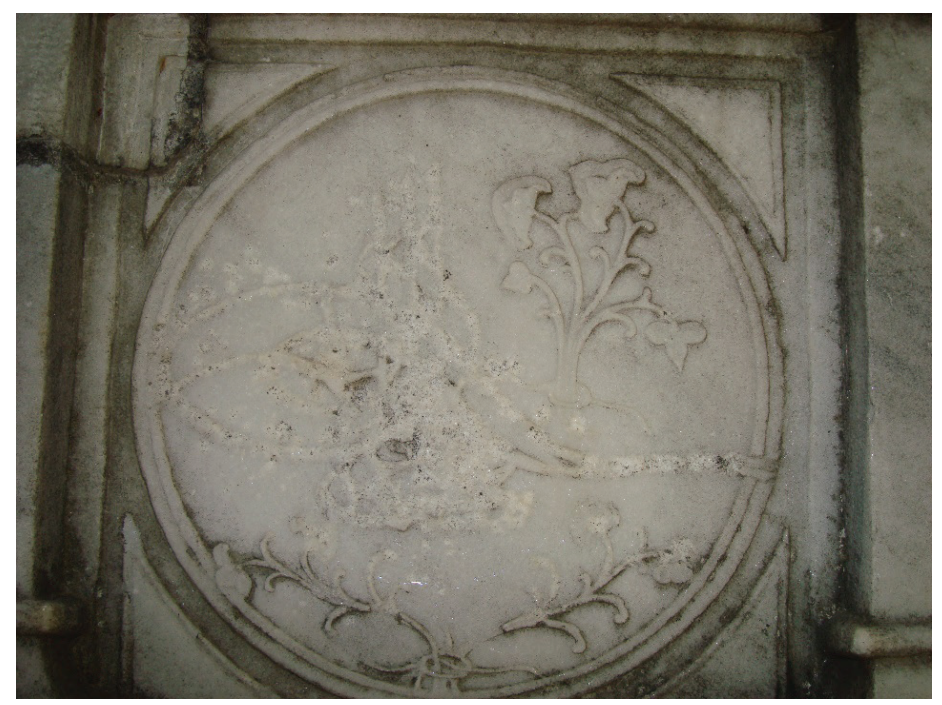

Resim 11. Meryem Kadın Çesmesi'nin kitâbesi yanlarında yer alan dairesel çerçeve içindeki tuğra ve etrafındaki bitkisel süslemelerden bir detay, 2008, (Zeynep Emel Ekim Arşivi)

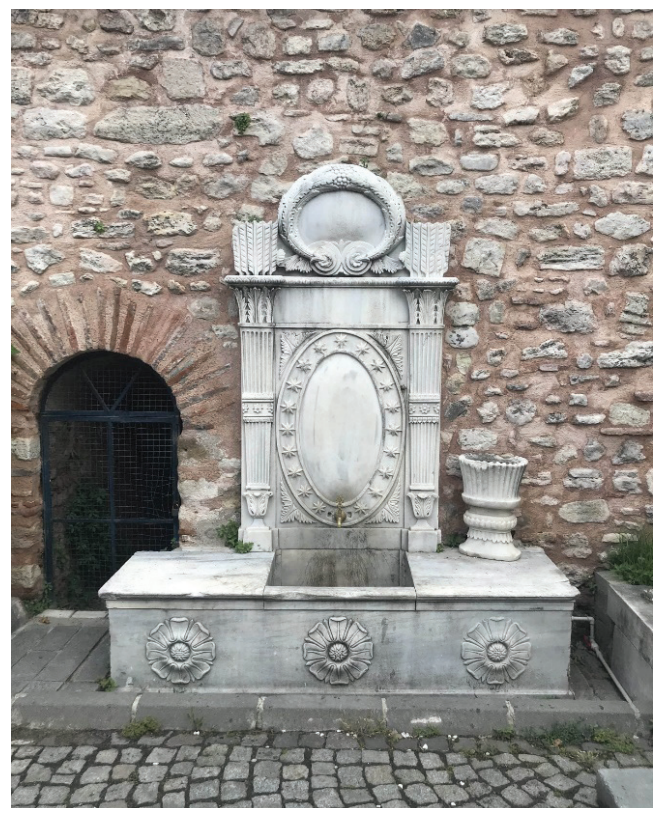

Resim 12. Sultan II. Mahmud Haziresi'nde yer alan bir çeşme, kulturenvanteri.com 


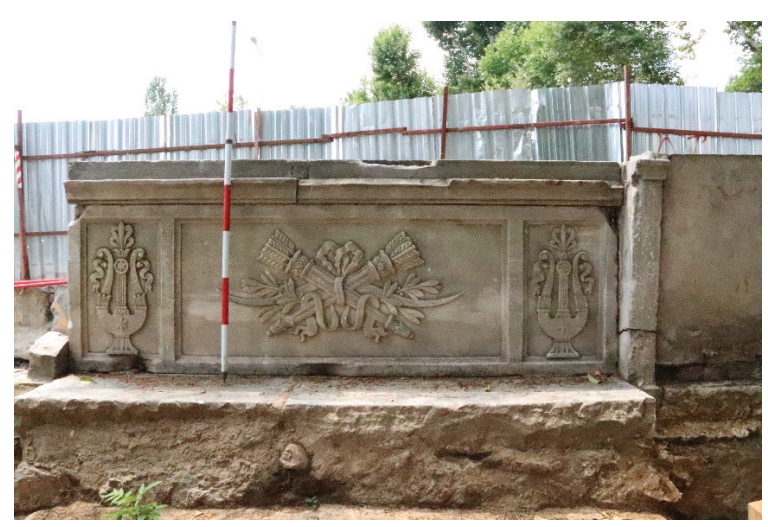

Resim 13. Abdülmecid Han Çeşmesi taç kısmının kazı sonrası, sarnıç yönünden bir görünümü, Arkeo Teknik Mimarlık ve Restorasyon Şirketi Arşivi

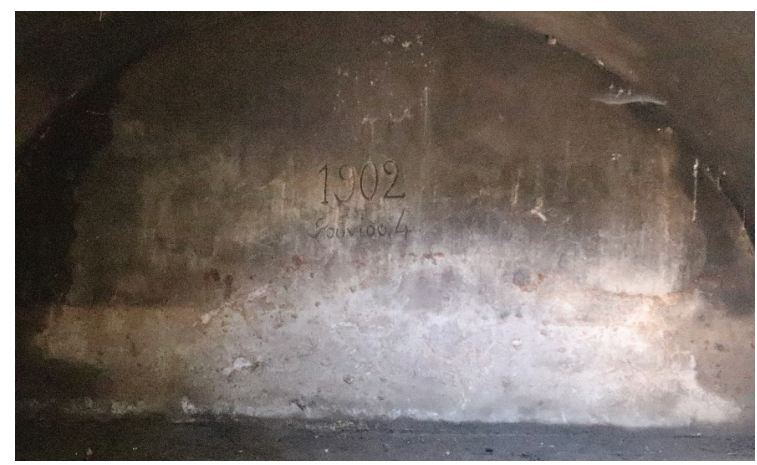

Resim 14. Abdülmecid Han Çeşmesi sarnıcının içten görünümü, Arkeo Teknik Mimarlık ve Restorasyon Şirketi Arşivi

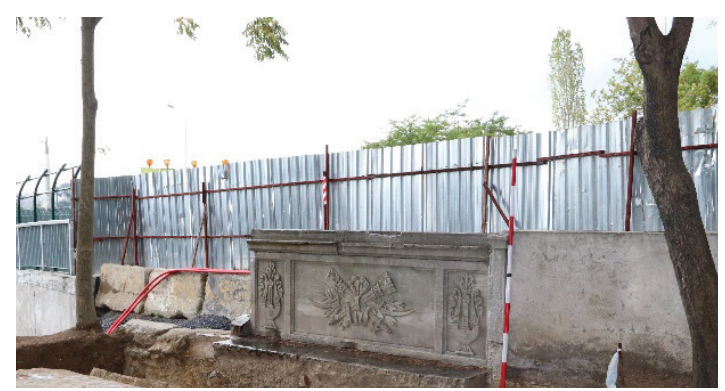

Resim 15. Abdülmecid Han Çeşmesi ve sarnıcının kazı sonrası bir görünümü, Arkeo Teknik Mimarlık ve Restorasyon Şirketi Arşivi 


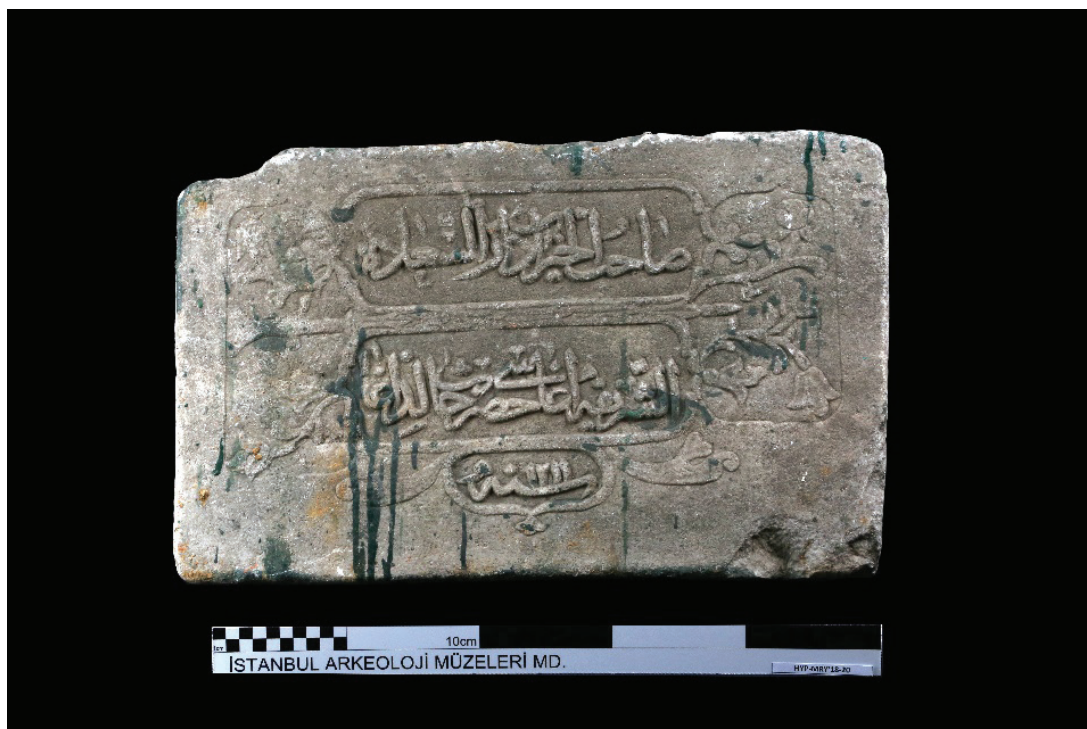

Resim 16. İstanbul Arkeoloji Müzeleri tarafından çıkarılan Halid Ağa Çeşmesi’nin ilk kitâbesi, İstanbul Arkeoloji Müzeleri Müdürlüğü Arşivi

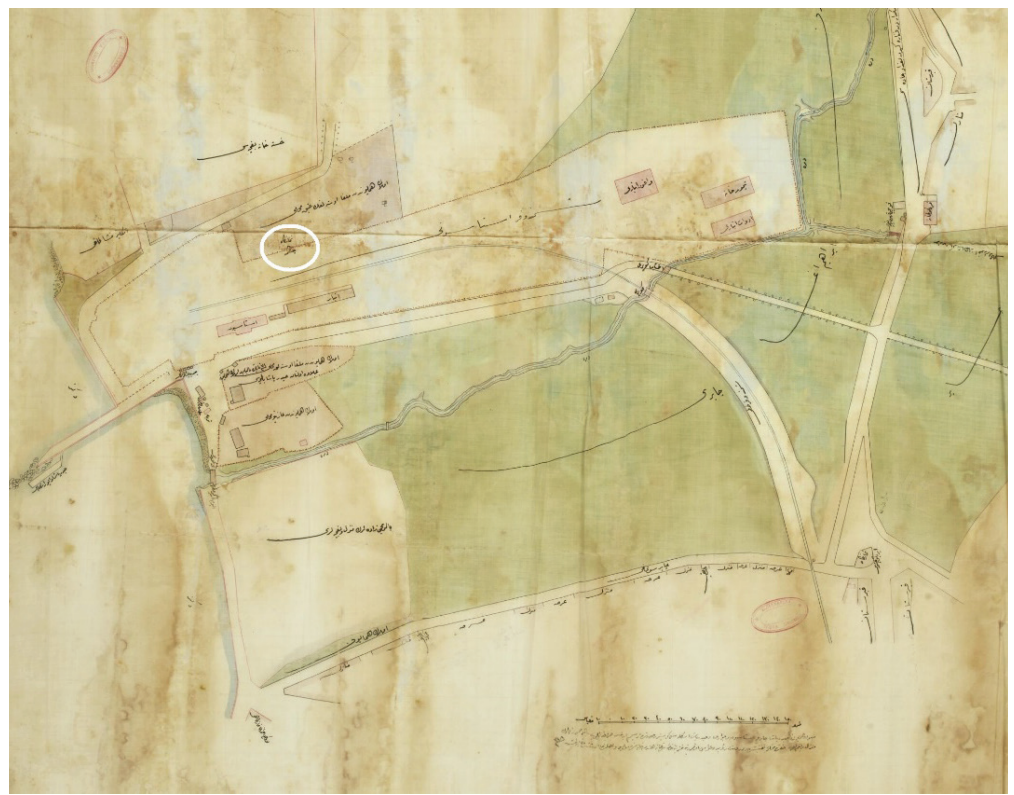

Resim 17. 1902 tarihli Haydarpaşa İstasyonu ve civarını gösteren kroki üzerinde Halid Ağa Çeşmesi'nin taşınmadan evvelki yeri, BOA. PLK. p. 389. 
